\title{
POSISI GVC INDONESIA DI WILAYAH ASEAN-KANADA
}

\section{Indonesia's Position on the GVC in the ASEAN-Canada Region}

\author{
Siti Mir'atul Khasanah, Dian Dwi Laksani, Nur Ulfa Mutiara Suwari \\ Pusat Pengkajian Kerjasama Perdagangan Internasional, Kementerian Perdagangan Republik \\ Indonesia, JI. M.I. Ridwan Rais 5, Jakarta Pusat, 10110, DKI Jakarta, Indonesia \\ Email: sitimiratulkhasanah@gmail.com
}

\begin{abstract}
Naskah diterima: 12/12/2019; Naskah direvisi: 21/02/2020; Disetujui diterbitkan: 24/08/2020;
\end{abstract} Dipublikasikan online: 0 /12/2020

\begin{abstract}
Abstrak
Rantai Nilai Global atau Global Value Chain (GVC) adalah alat yang berguna untuk melacak pola pergeseran dari produksi global. Kontribusi Indonesia dalam GVC di wilayah ASEANKanada masih rendah, hal ini dapat dilihat dari nilai intermediate input yang lebih rendah dibandingkan dengan nilai final input. Penelitian ini bertujuan untuk menganalisis posisi GVC Indonesia di wilayah ASEAN-Kanada. Penelitian ini menggunakan analisis input-output dengan berdasar pada data World Input Output Databases (WIOD). Hasil studi ini menunjukkan bahwa dalam lingkup ASEAN, kontribusi Indonesia dalam GVC masih rendah, dapat dilihat dari nilai intermediate input yang lebih rendah dari nilai final input. Bila dibandingkan dengan negara-negara lain ASEAN (yang memiliki ekspor terbesar ke Kanada) yaitu Vietnam, Thailand, dan Malaysia, persentase ekspor barang intermediate Indonesia hanya sebesar $48,3 \%$, lebih rendah dibandingkan negara-negara lainnya. Indonesia harus terus mengambil peran aktif di GVC. Di masa depan, Indonesia harus lebih aktif untuk dapat meningkatkan nilai tambah pada ekspor sebagai intermediate input, sehingga akan berdampak pada positif perekonomian Indonesia secara berkelanjutan.
\end{abstract}

Kata Kunci: ASEAN-Kanada FTA, GVC, Nilai Tambah

\begin{abstract}
Global Value Chain (GVC) is a useful tool to track shifting patterns of global production. Indonesia's contribution in GVC is still low, this can be seen from the lower intermediate input value compared to the final input value. The result of this study aims to analyze the position of Indonesia in the GVC in ASEAN-Canada region. The study used input-output analysis based on World Input Output Databases (WIOD). The study shows that within ASEAN, Indonesia's contribution in GVC is low, it can be seen from the input intermediate value which is lower than the final input value. When compared with other ASEAN countries (which have the largest exports to Canada), as Vietnam, Thailand, and Malaysia, the percentage of Indonesia's intermediate exports is only $48.3 \%$, which is lower than those of these countries. Indonesia should continue to take active role on GVC. In the future, Indonesia should be proactive to be able to increase added value on export as intermediate input. To indeed it will positively impact Indonesia's economy in a sustainable manner.
\end{abstract}

Keywords: ASEAN-Canada FTA, GVC, Added Value

JEL Classification: A11, B17, B22, B41

\section{PENDAHULUAN}

ASEAN-Kanada FTA termasuk kerja sama jangka panjang untuk memperkuat koneksi ekonomi yang bertujuan untuk menghilangkan tarif dan hambatan non-tarif dalam hampir semua perdagangan barang. ASEANKanada FTA menjadi salah satu strategi 
bisnis untuk kondisi ekonomi Indonesia, terutama untuk perbaikan daya saing di pasar global. ASEAN-Kanada FTA merupakan upaya ASEAN untuk memperluas dan memperdalam keterlibatan ekonomi dengan Kanada. Peluang akses pasar dapat mendorong pertumbuhan industri dalam negeri untuk meningkatkan efisiensi dalam proses produksi, baik dari bahan baku ke barang setengah jadi untuk kemudian diproses menjadi barang jadi, sehingga Indonesia dapat menjadi bagian dari rantai nilai global.

Kanada menjadi negara tujuan ekspor ke- 31 bagi Indonesia pada tahun 2019. ASEAN-Kanada FTA merupakan dorongan eksternal untuk mereformasi kondisi ekonomi Indonesia, terutama untuk peningkatan daya saing, hal ini karena saat ini (per 2011) kontribusi ekspor Indonesia terhadap GDP hanya $20 \%$, dibandingkan dengan Malaysia (79,3\%), Thailand (66,2\%), dan Singapura $(157,6 \%)$ serta peluang akses pasar yang lebih besar dengan rules yang seragam, dengan adanya Rules of Origin (ROO) yang seragam akan mendorong pertumbuhan industri di dalam negeri dengan memanfaatkan supply chain yang semakin efisien dan Indonesia menjadi bagian dari jaringan produksi global (global supply chain).

Kerja sama ASEAN-Kanada FTA dapat memfasilitasi perdagangan Indonesia sebagai upaya untuk meningkatkan nilai tambah dalam kerangka rantai nilai global. Hal ini dibuktikan bahwa perjanjian perdagangan bebas meningkatkan perdagangan Global Value Chain (GVC). Integrasi yang lebih dalam menumbuhkan fragmentasi produksi dengan struktur yang lebih seimbang di mana bahkan negara-negara yang kurang berkembang berpartisipasi di tahap hulu dan berkontribusi lebih banyak nilai domestik ditambahkan ke dalam rantai pasokan (Rubinova, 2017).

Perkembangan global value chain telah menyebabkan meningkatnya pemisahan proses produksi di seluruh dunia. Pergeseran ini memerlukan perubahan paradigma dalam pembuatan kebijakan. Indonesia seperti banyak negara lain memiliki keinginan besar untuk memperbaiki posisinya dalam global value chain.

Menurut Skabic (2019), partisipasi GVC telah menjadi salah satu indikator yang paling banyak digunakan untuk mengukur penyebaran proses produksi di antara berbagai negara. Partisipasi dalam GVC mampu meningkatkan nilai 
tambah pada sektor industri barang dan jasa. Tentu hal ini menjadi bukti bahwa GVC dapat memainkan peran sebagai opsi perdagangan bagi negara berkembang.

Pemerintah Indonesia sendiri sangat yakin bahwa rantai global ini mampu meningkatkan keunggulan komparatif pada komoditas ekspor unggulan. Indonesia saat ini telah mengembangkan 10 komoditas utama antara lain: tekstil dan produk tekstil (TPT), elektronik, karet dan produk karet, sawit, produk hasil hutan, alas kaki, otomotif, udang, kakao, dan kopi. Selain itu Indonesia memiliki 10 komoditas potensial yang juga diminati pasar internasional, seperti: produk kulit, peralatan medis, tanaman obat, makanan olahan, minyak atsiri, ikan dan produk perikanan, kerajinan, perhiasan, rempah-rempah dan peralatan kantor. Sehingga konsep global value chain sangat penting sebagai landasan memperbesar hubungan perdagangan internasional yang diawali dalam kerangka ASEAN-Kanada FTA.

Inisiasi ASEAN - Kanada perdagangan kerja sama dalam kerangka FTA pertama kali dibahas dalam SEOM-8 di Laos pada 2016. Sampai saat ini, keseriusan kedua belah pihak telah diwujudkan dalam dua kegiatan pertemuan melalui konferensi video yang berfokus pada diskusi tentang rencana pelaksanaan Joint Feasibility Study (JFS).

Terkait dengan GVC dalam rangka ASEAN-Canada, dalam penelitian ini bertujuan untuk menganalisis posisi Indonesia di GVC di kawasan ASEANKanada dengan menganalisis backward linkage dan forward linkage untuk sektor ekonomi di Indonesia dalam kerangka ASEAN-Kanada. Berdasarkan perhitungan indeks backward linkage dan indeks forward linkage, tingkat partisipasi Indonesia dalam GVC akan dianalisis dalam ruang lingkup ASEANKanada.

Dalam penelitian sebelumnya mengenai Indonesia Global Value Chain Participation in Regional Comprehensive Economic Partnership (RCEP), partisipasi Indonesia dalam rantai nilai global dalam ruang lingkup RCEP masih didominasi oleh Low Technology Industry yang menghasilkan bahan baku seperti logam dan mineral. Industri dalam kelompok ini adalah buruh industri intensif dan bahan bakunya berasal dari sumber daya alam di mana Indonesia memiliki keunggulan komparatif sebagai pemasok bahan bakunya (Ingot \& Laksani, 2019). 
GVC tidak hanya mencerminkan struktur input-output yang berbeda dari industri suatu negara secara lebih akurat, tetapi juga memberikan alasan yang kuat untuk menetapkan FTA (Zhou et al, 2019). Partisipasi dalam GVC sangat penting karena dapat menciptakan peluang-peluang pertumbuhan sehingga akan berdampak positif pada perkembangan ekonomi suatu kawasan (Sudhana, 2017). Dengan mengetahui posisi Indonesia di GVC di ASEAN-Kanada, ini akan membantu untuk membuat strategi ekonomi untuk Indonesia di masa yang akan datang.

\section{METODE}

Dalam menganalisis GVC terdapat beberapa metode yang bisa digunakan. Beberapa metode yang bisa digunakan yaitu Trade in Value Added (TiVA) dan Model Input-Output. TiVA digunakan untuk mengukur seberapa banyak nilai tambah dari produksi barang atau jasa suatu negara yang diekspor ke negara lain. Partisipasi GVC diukur dengan jumlah nilai asing ekspor atau impor di Indonesia dan jumlah nilai domestik yang ditambahkan di ekspor / impor negara lain (Ingot \& Laksani, 2019). Database TiVA terdiri dari serangkaian tools yang bertujuan untuk memberikan wawasan yang lebih baik tentang jaringan produksi global dan rantai pasokan dibandingkan dengan statistik perdagangan konvensional (OECD, 2019). Sedangkan model 10 adalah teknik yang mengkuantifikasi saling ketergantungan dalam sistem ekonomi yang saling berhubungan (Xing, 2017).

Dalam penelitian ini menggunakan metode analisis IO. Metode ini dipilih karena dengan menggunakan IO dapat melihat ekspor atau impor dari intermediate atau final goods dari suatu negara. Selain itu, data yang digunakan dalam metode 10 lebih update dibandingkan dengan TiVA. Sektorsektor dalam tabel 10 dapat dianggap sebagai poin sementara antar-sektor dalam memberikan kontribusi value stream untuk ditimbang dan diarahkan dalam pembangunan pengaturan model. Dalam pertimbangan dari kedua ketersediaan dan otoritas, tabel 10 menjadi sumber data prioritas pertama untuk membentuk model matematika, misalnya, dapat menunjukkan arus barang dan jasa akhir dan menengah. Selain itu, disediakan dalam matriks, yang dapat secara langsung atau dengan sedikit perubahan diadopsi sebagai pendekatan matriks ketetanggaan dalam membangun perpotongan yang lebih terarah. 
Indikator yang digunakan dalam perhitungan 10 yaitu intermediate input dan final demand. Selain itu indikator tersebut digunakan untuk membandingkan besaran GVC dengan negara ASEAN lainnya untuk melihat besaran keterlibatan Indonesia dalam Kanada.

Menurut Gereffi \& Stark (2011) dan Johnson \& Noguera (2012) dalam Lu (2017), di dalam analisis GVC mengidentifikasi empat dimensi analisis GVC, yaitu struktur input-output, ruang lingkup geografis, tata kelola dan konteks kelembagaan. Dalam empat dimensi, struktur input-output menjadi dasar analisis GVC. Namun, karena adanya perhitungan accounting yang ganda dan rantai produksi multi-negara, data perdagangan konvensional menjadi kurang dapat diandalkan untuk mengukur nilai yang dikontribusikan oleh suatu negara. World Input-Output Database (WIOD) dibangun dan diterbitkan oleh proyek yang didanai oleh European Commission. WIOD ini juga terbuka untuk akses publik. Hal ini memungkinkan kami untuk membuat analisis komprehensif tentang GVC dunia.

\section{Tabel 1. Data Input-Output Internasional}

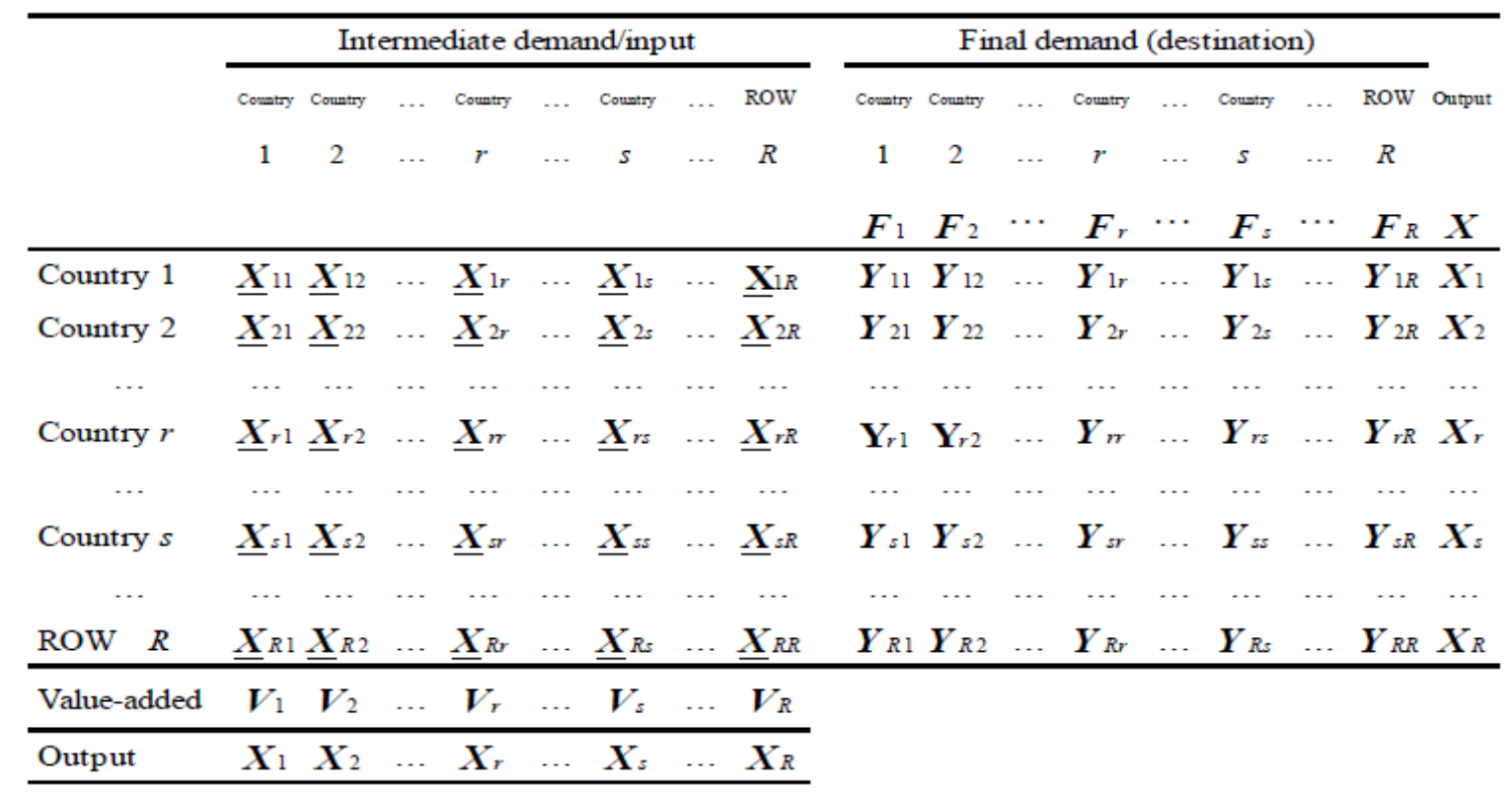

Sumber: Kuboniwa (2014)

Keterangan:

$\underline{X}_{r s}(s \neq r)$ :matriks ekspor bruto intermediate input negara $r$ ke negara s atau matriks impor bruto untuk intermediate in

$\begin{array}{ll}\underline{X}_{r r} & : \text { matriks intermediate input negara } r \text { yang diproduksi di dalam negeri } \\ \bar{V}_{r} & : \text { : vektor nilai tambah negara } r\end{array}$ 
Munculnya World Input Output Database (WIOD) secara teoritis dan empiris dapat membuat analisis GVC menjadi lebih baik, data WIOD terdiri dari rantai nilai industri internasional dan domestik yang sangat banyak, karena World Input Output Tables (WIOT) menyediakan alur global perdagangan bilateral secara konsisten, memungkinkan melihat perbandingan jaringan produksi di berbagai daerah (Tabel 1 ).

Untuk menunjukkan posisi Indonesia di GVC di ASEAN-Kanada, analisis ini menggunakan Analisis InputOutput untuk melihat dan membandingkan hubungan sektoral antar negara di ASEAN, khususnya Indonesia dan Kanada. Kapan nilai ekspor sebagai input antara lebih tinggi dari keterkaitan rantai nilai global yang lebih baik. Indikator ini didukung oleh indikator utama yaitu sektor ekspor Indonesia ke Kanada, sektor utama ekspor Kanada ke Indonesia, sektor dengan nilai ekspor terbesar untuk intermediate input dalam struktur ekspor Indonesia ke Kanada, sektor dengan nilai ekspor terbesar untuk intermediate input dalam struktur ekspor Kanada ke Indonesia, sektor dengan nilai ekspor terbesar untuk kategori final product dalam struktur ekspor Indonesia ke Kanada, dan sektor dengan nilai ekspor terbesar untuk kategori final product dalam struktur ekspor Kanada ke Indonesia.

Data yang digunakan dalam analisis ini adalah data sekunder dikumpulkan dari WIOD tahun terakhir yaitu tahun 2016, BPS, dan Trademap. Metode analisis yang digunakan adalah analisis input output.

\section{HASIL DAN PEMBAHASAN}

Dalam interaksi industri globalisasi saat ini, metode GVC adalah alat yang berguna untuk melacak pergeseran pola produksi global, hubungan aktivitas tersebar dan pelaku industri, dan menentukan peran mereka bermain di negara lain.

Dengan mengintegrasikan negaranegara ke dalam ekonomi dunia, globalisasi telah menghasilkan spesialisasi regional industri serta pemindahan produksi dan konsumsi barang atau jasa. Oleh karena itu, setiap negara harus hati-hati menunjukkan posisi dalam rantai pasokan global dan menyesuaikan struktur industri mereka untuk mendorong pembangunan ekonomi dan penggunaan energi yang berkelanjutan pada saat yang bersamaan (Chen et al, 2019).

Nilai ekspor yang tinggi tidak selalu merepresentasikan nilai tambah 
ekonomi suatu negara, tetapi juga dengan mempertimbangkan nilai impor negara lain (Hummels et al. 2001). Nilai tambah diilustrasikan dengan produksi iPhone, pembuatannya berlangsung di Cina, sementara perangkat keras diproduksi di Jepang, memori datang dari Korea Selatan, dan prosesor berasal dari AS, untuk pemasaran ritel lebih lanjut di AS dan yang bagian lainnya dari negara lain (Dedric et al. 2010). Proses ini akan membentuk GVC di mana masing-masing negara menyediakan bahan baku, barang setengah jadi hingga barang jadi yang akan digunakan konsumen (Gereffi, 2014).

Rantai nilai menggambarkan rangkaian lengkap kegiatan yang dilakukan oleh perusahaan dan pekerja untuk produk dari konsepsinya hingga penggunaan akhir dan seterusnya. Kegiatan termasuk desain, produksi, pemasaran, distribusi, dan dukungan pada konsumen akhir. Kegiatan yang terdiri dari: rantai nilai dapat terkandung dalam satu perusahaan atau dibagi di antara perusahaan yang berbeda (globalvaluechains.org, 2019). Banga (2016), partisipasi suatu negara dalam GVC ditentukan oleh sejauh mana keterlibatannya dengan suatu bagian tertentu dari suatu proses produksi, yaitu perdagangan barang dan jasa dengan hasil setengah jadi.

Ekonomi global semakin terstruktur di antara rantai nilai global yang menyumbang meningkatnya pangsa perdagangan internasional, PDB global, dan lapangan kerja. Evolusi GVC di sektor yang beragam seperti komoditas, pakaian, elektronik, pariwisata, dan outsourching layanan bisnis memiliki implikasi yang signifikan dalam hal perdagangan global, produksi, pekerjaan dan bagaimana perusahaan di negara berkembang, produsen serta para pekerja yang terintegrasi dalam ekonomi global (Gereffi \& Stark, 2011).

Industri GVC ditemukan tidak hanya di negara tertentu, tetapi juga di banyak negara dan dari banyak sektor lainnya. Sebagai contoh kasus dari tiga negara di mana negara pertama memproduksi barang setengah jadi dan barang jadi untuk negara yang kedua (Meng, 2011; Koopman et al. 2010); dan negara kedua memproduksi untuk kebutuhan domestik negaranya serta selanjutnya di ekspor ke negara ketiga. Proses pembuatan di negara kedua membutuhkan bahan baku berupa barang, modal dan tenaga kerja. Adapun untuk ekspor ke negara ketiga ini dapat berbentuk barang setengah 
jadi dan barang akhir. Artinya, karena barang tersebut di produksi di beberapa negara sehingga proses produksi tersebut memiliki implikasi di masingmasing negara yang memproduksi dan hal tersebut akan menjadi nilai tambah tertentu dalam suatu perdagangan (Timmer et al. 2014). Proses yang sama melibatkan banyak negara akan membentuk GVC di mana masingmasing negara dengan sumber dayanya berpartisipasi satu atau lebih dari suatu proses produksi (Johson \& Noguera, 2012).

GVC menjadi fenomena global sejak 1980-an ketika nilai ekspor tidak lagi mewakili manfaat nyata dari ukuran ekonomi suatu negara. Pengukuran GVC yang menerapkan pendekatan tabel IO telah cukup berkembang pesat (Ahmad, dkk, 2018). GVC adalah revolusi sistem produksi di abad ke-21 dimana produksi dan distribusi barang diadakan bersama beberapa negara. Satu tahap produksi proses produksi tunggal diadakan di satu negara sedangkan tahap berikutnya dilakukan di negara lain. GVC cenderung meningkat dengan komunikasi dan logistik revolusi teknologi. Salah satu contoh GVC adalah sistem produksi kendaraan bermotor di Asia yang telah melibatkan produksi dan distribusi satu jenis kendaraan di beberapa negara di kawasan itu di mana komponen dari kendaraan bermotor yang diproduksi di berbagai negara saat perakitan dilakukan di negara-negara lain di Asia (EU-Indonesia Trade Cooperation Facility, 2015). Indonesia dalam hal eksportir di Kanada dapat dilihat pada Gambar 1.

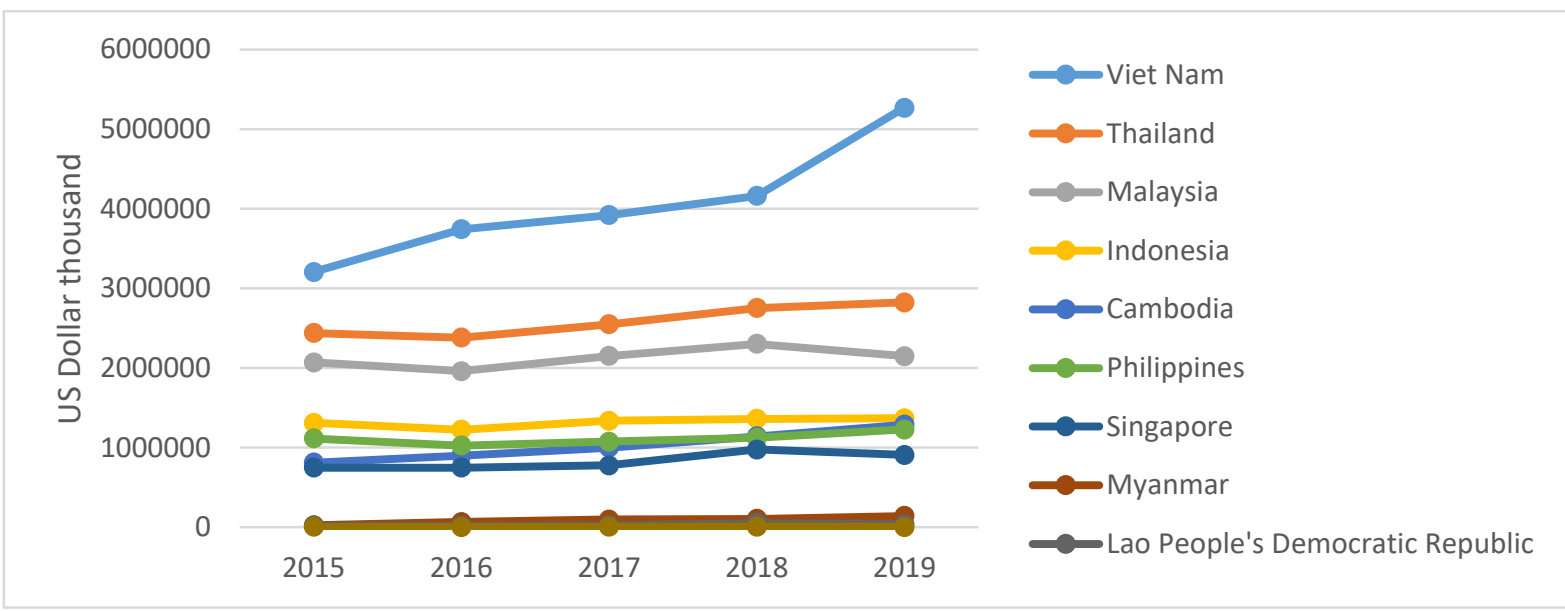

Gambar 1. Daftar Pemasok Pasar Kanada dari ASEAN

Sumber: Trademap (2020) 
Pada Gambar 1 menunjukkan pada tahun 2019 Indonesia berada di posisi empat sebagai pemasok ke pasar Kanada setelah Vietnam, Thailand dan Malaysia dengan total USD 1.367.658 ribu. Salah satu indikator makroekonomi adalah GDP. Dari Tabel 2 diketahui bahwa GDP ASEAN pada lima tahun terakhir terus mnengalami peningkatan, untuk tahun 2019 GDP ASEAN sebesar
3.190 miliar USD. Sedangkan GDP Kanada dalam lima tahun terakhir juga mengalami kenaikan meskipun pada tahun 2016 mengalami penurunan. Diantara Negara-Negara di ASEAN, Indonesia merupakan negara dengan jumlah GDP terbesar yaitu 1.163 miliar USD pada tahun 2019 dan dalam kurun waktu lima tahun terakhir GDP Indonesia selalu mengalami kenaikan.

Tabel 2. GDP ASEAN Kanada (2015-2019)

\begin{tabular}{lrrrrr}
\hline \multirow{2}{*}{ NEGARA } & \multicolumn{5}{c}{ Tahun (dalam miliar USD) } \\
\cline { 2 - 6 } & \multicolumn{1}{c}{$\mathbf{2 0 1 5}$} & $\mathbf{2 0 1 6}$ & $\mathbf{2 0 1 7}$ & $\mathbf{2 0 1 8}$ & $\mathbf{2 0 1 9}$ \\
\hline ASEAN & 2,476 & 2,606 & 2,791 & 2,946 & 3,190 \\
Brunei & 13 & 11 & 12 & 14 & 14 \\
Cambodia & 18 & 20 & 22 & 25 & 27 \\
Canada & 1,557 & 1,528 & 1,650 & 1,716 & 1,740 \\
Indonesia & 861 & 932 & 1,015 & 1,042 & 1,163 \\
Laos & 14 & 16 & 17 & 18 & 17 \\
Malaysia & 301 & 301 & 319 & 359 & 369 \\
Myanmar & 63 & 65 & 67 & 68 & 76 \\
Philippines & 292 & 304 & 313 & 331 & 359 \\
Singapore & 308 & 318 & 338 & 364 & 365 \\
Thailand & 401 & 412 & 455 & 505 & 544 \\
Vietnam & 237 & 252 & 277 & 303 & 340 \\
\hline
\end{tabular}

Sumber: The Economist Intelligence Unit (2020)

Selain GDP, populasi juga merupakan indikator makroekonomi suatu negara. Populasi dari ASEANKanada dapat dilihat pada Tabel 3 . Pada tahun 2015-2019 di antara negara-negara anggota ASEAN dan Kanada yang memiliki populasi terbesar yaitu Indonesia dengan jumlah sebanyak 265,3 juta jiwa pada tahun 2019 dan dalam kurun waktu lima tahun terakhir populasi Indonesia selalu mengalami kenaikan yang cukup banyak. Sedangkan untuk wilayah ASEAN, populasi pada tahun 2019 adalah sebanyak 654,8 juta jiwa. 
Tabel 3. Populasi ASEAN-Kanada (2015-2019)

\begin{tabular}{|c|c|c|c|c|c|}
\hline \multirow{2}{*}{ NEGARA } & \multicolumn{5}{|c|}{ Tahun (dalam Juta Jiwa) } \\
\hline & 2015 & 2016 & 2017 & 2018 & 2019 \\
\hline ASEAN & 630 & 636.4 & 642.6 & 648.7 & 654.8 \\
\hline Brunei & 0.4 & 0.4 & 0.4 & 0.4 & 0.4 \\
\hline Cambodia & 15.5 & 15.8 & 16 & 16.3 & 16.5 \\
\hline Canada & 36 & 36.4 & 36.7 & 37.1 & 37.4 \\
\hline Indonesia & 255.8 & 258.2 & 260.6 & 262.9 & 265.3 \\
\hline Laos & 6.7 & 6.8 & 7 & 7.1 & 7.2 \\
\hline Malaysia & 30.3 & 30.7 & 31.1 & 31.5 & 32 \\
\hline Myanmar & 52.7 & 53 & 53.4 & 53.7 & 54.1 \\
\hline Philippines & 102.1 & 103.7 & 105.2 & 106.7 & 108.1 \\
\hline Singapore & 5.5 & 5.6 & 5.6 & 5.6 & 5.7 \\
\hline Thailand & 68.7 & 69 & 69.2 & 69.4 & 69.6 \\
\hline Vietnam & 92.7 & 93.6 & 94.6 & 95.6 & 96.5 \\
\hline
\end{tabular}

Sumber: The Economist Intelligence Unit (2020)

Populasi Kanada dalam lima tahun terakhir mengalami kenaikan meskipun hanya sedikit. Pada tahun 2019 jumlah populasi Kanada sebanyak 37,4 juta

Kinerja perdagangan antara Indonesia dan Kanada dapat dilihat melalui neraca perdagangan kedua negara (Gambar 2). jiwa.

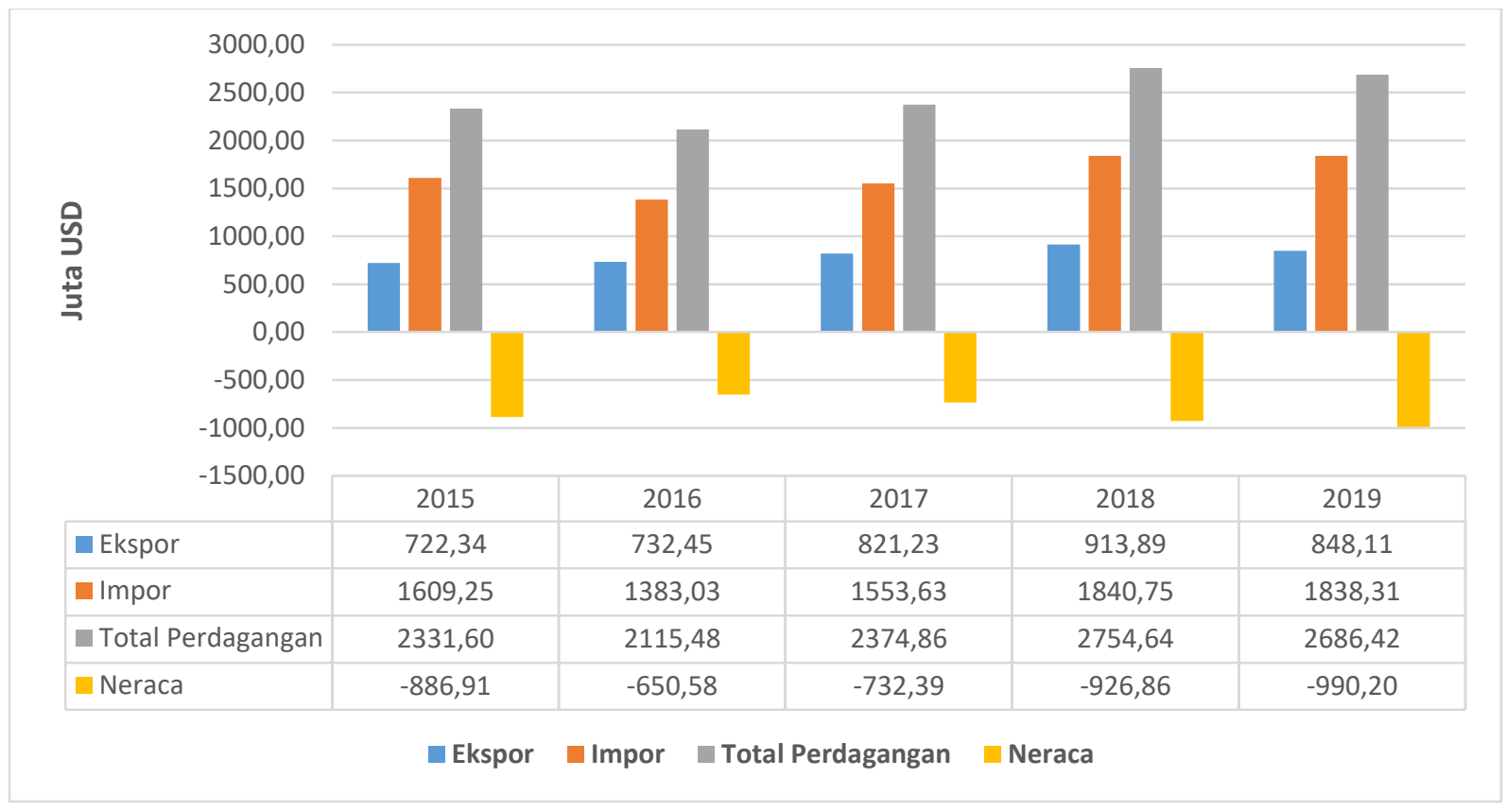

\section{Gambar 2. Neraca Perdagangan Indonesia-Kanada}

Sumber: BPS (2020) 
Dari Gambar 2 dapat diketahui bahwa dari tahun 2015 - 2019 kinerja perdagangan Indonesia di Kanada mengalami defisit. Ekspor Indonesia ke Kanada selama lima tahun terakhir mengalami kenaikan dengan trend sebesar $5.57 \%$, meskipun pada tahun 2019 mengalami penurunan dari tahun sebelumnya. Sedangkan untuk impor
Indonesia dari Kanada memiliki trend yang positif yaitu sebesar 5.68\% di mana lebih tinggi daripada trend kenaikan ekspornya. Dari tahun 20152019 total perdagangan terbesar Indonesia-Kanada terjadi pada tahun 2018 yaitu sebesar USD 2754.64 Juta. Jika dilihat berdasarkan produk, ekspor Indonesia ke Kanada lihat Tabel 4.

Tabel 4. Ekspor Indonesia ke Kanada

\begin{tabular}{|c|c|c|c|c|c|c|c|}
\hline \multirow{2}{*}{ No } & \multirow[b]{2}{*}{ HS } & \multirow[b]{2}{*}{ URAIAN } & \multicolumn{5}{|c|}{ NILAI : Juta USD } \\
\hline & & & 2015 & 2016 & 2017 & 2018 & 2019 \\
\hline 1 & 400122 & $\begin{array}{l}\text { Rubber; Technically Specified } \\
\text { Natural Rubber (Tsnr), In Primary } \\
\text { Forms Or In Plates, Sheets Or Strip } \\
\text { (Excluding Latex And Smoked } \\
\text { Sheets) }\end{array}$ & 108.41 & 94.94 & 151.12 & 124.34 & 101.23 \\
\hline 2 & 640411 & $\begin{array}{l}\text { Sports Footwear; Tennis Shoes, } \\
\text { Basketball Shoes, Gym Shoes, } \\
\text { Training Shoes And The Like, With } \\
\text { Outer Soles Of Rubber Or Plastics } \\
\text { And Uppers Of Textile Materials }\end{array}$ & 18.68 & 22.83 & 15.22 & 17.76 & 31.20 \\
\hline & & $\begin{array}{l}\text { Iron Or Non-Alloy Steel; Bars And } \\
\text { Rods, Hot-Rolled, Hot-Drawn Or } \\
\text { Hot-Extruded, Containing }\end{array}$ & & & & & \\
\hline 3 & 721420 & $\begin{array}{l}\text { Indentations, Ribs, Grooves Or } \\
\text { Other Deformations Produced } \\
\text { During The Rolling Process Or } \\
\text { Twisted After Rolling } \\
\text { Vehicle Parts; Drive-Axles With } \\
\text { Differential, Whether Or Not }\end{array}$ & 0.00 & 0.00 & 8.10 & 23.09 & 31.20 \\
\hline 4 & 870850 & $\begin{array}{l}\text { Provided With Other Transmission } \\
\text { Components, And Non-Driving } \\
\text { Axles; Parts Thereof } \\
\text { Uncoated Paper And Paperboard } \\
\text { (Not } 4801 \text { Or } 4803 \text { ); Printing, Writing } \\
\text { Or Graphic, } 10 \% \text { Or Less By Weight }\end{array}$ & 0.00 & 0.00 & 13.92 & 47.13 & 27.57 \\
\hline 5 & 480256 & $\begin{array}{l}\text { Of Mechanical Or Chemi-Mechanical } \\
\text { Processed Fibre, Weight } 40- \\
\text { 150G/M2, In Sheets } 435 \mathrm{Mm} \text { Or Less } \\
\text { By } 297 \mathrm{Mm} \text { Or Less (Unfolded) }\end{array}$ & 23.56 & 25.32 & 18.16 & 29.74 & 24.85 \\
\hline 6 & 090111 & $\begin{array}{l}\text { Coffee; Not Roasted Or } \\
\text { Decaffeinated }\end{array}$ & 23.11 & 21.59 & 22.08 & 19.20 & 23.63 \\
\hline 7 & 180400 & Cocoa; Butter, Fat And Oil & 18.88 & 44.30 & 45.11 & 42.23 & 22.17 \\
\hline
\end{tabular}




\begin{tabular}{|c|c|c|c|c|c|c|c|}
\hline \multirow[b]{2}{*}{ No } & \multirow[b]{2}{*}{ HS } & \multirow[b]{2}{*}{ URAIAN } & \multicolumn{5}{|c|}{ NILAI : Juta USD } \\
\hline & & & 2015 & 2016 & 2017 & 2018 & 2019 \\
\hline 8 & 640319 & $\begin{array}{l}\text { Sports Footwear; (Other Than Ski- } \\
\text { Boots, Snowboard Boots Or Cross- } \\
\text { Country Ski Footwear), With Outer } \\
\text { Soles Of Rubber, Plastics, Leather } \\
\text { Or Composition Leather And Uppers } \\
\text { Of Leather }\end{array}$ & 12.34 & 13.01 & 15.64 & 18.72 & 18.07 \\
\hline 9 & 730630 & $\begin{array}{l}\text { Iron Or Non-Alloy Steel (Excluding } \\
\text { Cast Iron); Tubes And Pipes (Not } \\
\text { Seamless), Welded, Of Circular } \\
\text { Cross-Section, N.E.C. In Chapter } 73\end{array}$ & 0.73 & 0.92 & 5.00 & 9.14 & 16.93 \\
\hline 10 & 841199 & $\begin{array}{l}\text { Turbines; Parts Of Gas Turbines } \\
\text { (Excluding Turbo-Jets And Turbo- } \\
\text { Propellers) }\end{array}$ & 0.01 & 0.00 & 0.00 & 6.12 & 15.10 \\
\hline & & Sub Total & 205.72 & 222.92 & 294.34 & 337.47 & 311.95 \\
\hline & & Lainnya & 516.63 & 509.53 & 526.89 & 576.42 & 536.15 \\
\hline & & Jumlah & 722.34 & 732.45 & 821.23 & 913.89 & 848.11 \\
\hline
\end{tabular}

Sumber: Trade map (2020), diolah

Sepuluh produk ekspor utama Indonesia ke Kanada dalam lima tahun terakhir jika dilihat dari HS 6 digit BTKI tahun 2017 di dominasi oleh Rubber; Technically Specified Natural Rubber (Tsnr), In Primary Forms Or In Plates, Sheets Or Strip (Excluding Latex And Smoked Sheets) sebanyak USD 101.23 juta pada tahun 2019, di urutan kedua adalah Sports Footwear; Tennis Shoes, Basketball Shoes, Gym Shoes, Training Shoes And The Like, With Outer Soles Of Rubber Or Plastics And Uppers Of Textile Materials sebanyak USD 31.20 juta pada tahun 2019 dan Iron Or NonAlloy Steel; Bars And Rods, Hot-Rolled,
Hot-Drawn Or Hot-Extruded, Containing Indentations, Ribs, Grooves Or Other Deformations Produced During The Rolling Process Or Twisted After Rolling sebanyak USD 31.20 juta pada tahun 2019.

Jika dilihat dari total ekspor untuk 10 produk tersebut dengan sejumlah USD 311.95 juta pada tahun 2019, jumlah tersebut berkontribusi sebanyak $37 \%$ dari total keseluruhan ekspor Indonesia ke Kanada yaitu sebanyak USD 848.11. Sementara jika dilihat berdasarkan produk, maka impor Indonesia dari Kanada dapat dilihat pada tabel 5 . 
Tabel 5. Impor Indonesia dari Kanada

\begin{tabular}{|c|c|c|c|c|c|c|c|}
\hline \multirow[b]{2}{*}{ No } & \multirow[b]{2}{*}{ HS } & \multirow[b]{2}{*}{ URAIAN } & \multicolumn{5}{|c|}{ NILAI : juta USD } \\
\hline & & & 2015 & 2016 & 2017 & 2018 & 2019 \\
\hline 1 & 100199 & $\begin{array}{l}\text { Cereals; Wheat And Meslin, } \\
\text { Other Than Durum Wheat, Other } \\
\text { Than Seed }\end{array}$ & 533.31 & 445.48 & 485.36 & 571.68 & 701.94 \\
\hline 2 & 310420 & $\begin{array}{l}\text { Fertilizers, Mineral Or Chemical; } \\
\text { Potassic, Potassium Chloride } \\
\text { Wood Pulp; Chemical Wood }\end{array}$ & 425.32 & 310.82 & 301.69 & 361.29 & 300.35 \\
\hline 3 & 470321 & $\begin{array}{l}\text { Pulp, Soda Or Sulphate, (Other } \\
\text { Than Dissolving Grades), Semi- } \\
\text { Bleached Or Bleached, Of }\end{array}$ & & & & & \\
\hline & & $\begin{array}{l}\text { Coniferous Wood } \\
\text { Wood Pulp; Chemical Wood }\end{array}$ & 182.60 & 196.64 & 253.39 & 304.54 & 192.77 \\
\hline 4 & 470200 & Pulp, Dissolving Grades & 72.52 & 72.84 & 72.12 & 82.50 & 70.40 \\
\hline 5 & 120190 & $\begin{array}{l}\text { Soya Beans; Other Than Seed, } \\
\text { Whether Or Not Broken } \\
\text { Aircraft And Spacecraft; Parts Of }\end{array}$ & 13.51 & 3.70 & 5.88 & 24.73 & 52.70 \\
\hline 6 & 880330 & $\begin{array}{l}\text { Aeroplanes Or Helicopters } \\
\text { N.E.C. In Heading No. } 8803\end{array}$ & 1.41 & 2.84 & 13.43 & 20.50 & 49.94 \\
\hline 7 & 470100 & $\begin{array}{l}\text { Wood Pulp; Mechanical Wood } \\
\text { Pulp } \\
\text { Crustaceans; Frozen, Crabs, In } \\
\text { Shell Or Not, Smoked, Cooked }\end{array}$ & 39.29 & 37.67 & 47.90 & 60.87 & 34.83 \\
\hline 8 & 030614 & $\begin{array}{l}\text { Or Not Before Or During } \\
\text { Smoking; In Shell, Cooked By }\end{array}$ & & & & & \\
\hline 9 & 260111 & $\begin{array}{l}\text { Steaming Or By Boiling In Water } \\
\text { Iron Ores And Concentrates; } \\
\text { Non-Agglomerated }\end{array}$ & 15.15 & $\begin{array}{l}13.03 \\
15.20\end{array}$ & 28.66 & 23.70 & $\begin{array}{l}30.32 \\
22.48\end{array}$ \\
\hline & & $\begin{array}{l}\text { Wood Pulp; Chemical Wood } \\
\text { Pulp, Soda Or Sulphate, (Other }\end{array}$ & & & & & \\
\hline 10 & 470311 & $\begin{array}{l}\text { Than Dissolving Grades), } \\
\text { Unbleached, Of Coniferous }\end{array}$ & & & & & \\
\hline & & Wood & 7.97 & 14.94 & 13.87 & 20.51 & 19.28 \\
\hline & & Subtotal & 1306.42 & 1113.15 & 1256.53 & 1514.55 & 1475.01 \\
\hline & & Lainnya & 302.83 & 269.88 & 297.10 & 326.20 & 363.30 \\
\hline & & Total & 1609.25 & 1383.03 & 1553.63 & 1840.75 & 1838.31 \\
\hline
\end{tabular}

Sumber: Trademap (2020), diolah

Sepuluh produk impor utama Indonesia dari Kanada dalam lima tahun terakhir jika dilihat dari HS 6 digit BTKI tahun 2017 di dominasi oleh Cereals; Wheat And Meslin, Other Than Durum Wheat, Other Than Seed sebanyak USD 701.94 juta pada tahun 2019, di urutan kedua adalah Fertilizers, Mineral
Or Chemical; Potassic, Potassium Chloride sebanyak USD 300.35 Juta pada tahun 2019 dan Wood Pulp; Chemical Wood Pulp, Soda Or Sulphate, (Other Than Dissolving Grades), Semi-Bleached Or Bleached, Of Coniferous Wood sebanyak USD 192.77 Juta pada tahun 2019. 
Jika dilihat dari total impor untuk 10 produk tersebut dengan sejumlah USD 1475.01 Juta pada tahun 2019, jumlah tersebut berkontribusi sebanyak $80 \%$ dari total keseluruhan impor Indonesia dari Kanada yaitu sebanyak USD 848.11 Juta

\section{Analisis World Input Output Database (WIOD)}

Analisis WIOD merupakan Tabel Input-Output antar negara yang dipublikasi oleh Uni Eropa (EU). Data WIOD yang dipublikasi mencakup 43 negara dengan 56 sektor klasifikasi 4 ISIC. Dibandingkan data Input-Output antar negara yang lain, data WIOD termasuk data tabel Input-Output dunia yang relative selalu menampilkan data terbaru.

Untuk mengukur seberapa besar dampak atau manfaat yang akan ditimbulkan dengan adanya FTA ASEAN-Kanada bagi Indonesia, maka penting untuk diperhatikan keterkaitan sektoral antara Kanada dan Indonesia.
Oleh karena itu digunakan tabel World Input Output Database (WIOD) yang dihitung dan dipublikasikan oleh Timmer et al (2016). Data WIOD yang digunakan adalah data WIOD tahun 2014 yang dipublikasikan pada tahun 2016 dan mencakup 43 negara dan 56 sektor.

Bila dilihat dari Tabel 4, struktur perdagangan Indonesia-Kanada, maka sebagian besar ekspor Kanada ke Indonesia dan juga sebaliknya lebih didominasi oleh produk-produk yang dapat dikategorikan sebagai barang intermediate. Dengan kata lain, produk tersebut digunakan kembali sebagai input dalam produksi. Persentase produk intermediate pada struktur ekspor kedua belah negara adalah 48,3\% untuk ekspor Indonesia ke Kanada dan 71,9\% untuk ekspor Kanada ke Indonesia.

Berdasarkan Tabel 6, Apabila dibandingkan dengan Negara ASEAN lainnya (yang memiliki ekspor terbesar

Tabel 6. Analisis Input-Output

\begin{tabular}{lrrrrr}
\hline \multicolumn{1}{c}{ Export } & $\begin{array}{c}\text { Indonesia } \\
\text { ke Kanada }\end{array}$ & $\begin{array}{r}\text { Kanada ke } \\
\text { Indonesia }\end{array}$ & $\begin{array}{c}\text { Vietnam } \\
\text { ke } \\
\text { Kanada }\end{array}$ & $\begin{array}{c}\text { Thailand } \\
\text { ke Kanada }\end{array}$ & $\begin{array}{c}\text { Malaysia } \\
\text { ke Kanada }\end{array}$ \\
\hline Total trade (million USD) & $1,714,343$ & $3,252,175$ & 375,214 & 905,058 & 786,760 \\
Share Export ke Kanada & $0.094 \%$ & $0.042 \%$ & $0.132 \%$ & $0.425 \%$ & $0.268 \%$ \\
\% export as intermediate & $48.3 \%$ & $71.9 \%$ & $52.2 \%$ & $50.6 \%$ & $66.3 \%$ \\
input & & & & & \\
\% export as final demand & $51.7 \%$ & $28.1 \%$ & $47.8 \%$ & $49.4 \%$ & $33.7 \%$ \\
\hline
\end{tabular}

Sumber: WIOD (2019), diolah 
ke Kanada) yaitu Vietnam, Thailand, dan Malaysia maka persentase ekspor intermediate input Indonesia hanya sebesar 48,3\% dimana jumlah tersebut lebih rendah dibandingkan dengan
Negara-Negara tersebut. Jika nilai intermediate inputnya tinggi maka Negara tersebut memiliki keterkaitan rantai nilai global yang lebih bagus.

Tabel 7. Sepuluh Sektor Utama Ekspor Indonesia ke Kanada

\begin{tabular}{llrr}
\hline No & \multicolumn{1}{c}{ Sectors } & $\begin{array}{r}\text { total export } \\
\text { (million USD) }\end{array}$ & \%total \\
\hline 1 & Manufacture of textiles, wearing apparel and leather products & 688.84 & $35.1 \%$ \\
2 & Manufacture of rubber and plastic products & 346.93 & $17.7 \%$ \\
3 & Manufacture of food products, beverages and tobacco products & 278.80 & $14.2 \%$ \\
4 & Manufacture of furniture; other manufacturing & 143.83 & $7.3 \%$ \\
5 & Manufacture of computer, electronic and optical products & 88.73 & $4.5 \%$ \\
6 & Crop and animal production, hunting and related service & 57.44 & $2.9 \%$ \\
& activities & & \\
7 & Manufacture of basic metals & 37.92 & $1.9 \%$ \\
8 & Manufacture of wood and of products of wood and cork, except & 36.00 & $1.8 \%$ \\
& furniture; manufacture of articles of straw and plaiting materials & & \\
9 & Manufacture of chemicals and chemical products & 33.99 & $1.7 \%$ \\
10 & Manufacture of machinery and equipment n.e.c. & 33.96 & $1.7 \%$ \\
\hline
\end{tabular}

Sumber: WIOD (2019)

Secara lebih rinci, Tabel 7 menyajikan 10 sektor utama yang memiliki nilai ekspor terbesar untuk ekspor Indonesia ke Kanada. Secara umum dapat dilihat bahwa ekspor Indonesia ke Kanada didominasi oleh sektor tekstil, karet, dan produk makanan, yakni sebesar 48,3\% dari total nilai ekspor Indonesia ke Kanada. Sektor tekstil merupakan kotribusi ekspor terbesar dari Indonesia ke Kanada yaitu sebesar 35,1\%.

Selain tekstil, karet dan sektor produk makanan juga memiliki kontribusi yang cukup besar terhadap total ekspor Indonesia ke Kanada, yakni masing-masing sebesar $17,7 \%$ dan $14,2 \%$. Secara keseluruhan, ketiga sektor di atas telah menyumbang sebesar lebih dari $50 \%$ dari total nilai ekspor Indonesia ke Kanada. Hal tersebut mencerminkan adanya peluang bagi Indonesia untuk melakukan penetrasi pasar Kanada lebih dalam lagi, khususnya dengan memfokuskan kepada sektor-sektor lain yang memiliki daya saing tinggi. Jika melihat struktur Kanada ekspor ke Indonesia, Tabel 8 menunjukkan bahwa Kanada ekspor juga masih 
terkonsentrasi di empat sektor utama, yaitu sektor pertambangan dan mineral, sektor peralatan transportasi, makanan sektor produk hewani tanaman dan sektor basic metal. Secara bersamasama keempat sektor tersebut berkontribusi sebesar $51,7 \%$ dari total nilai ekspor Kanada ke Indonesia. Satu yang menarik adalah ada keterkaitan yang cukup erat antara sektor basic metal Kanada dengan Indonesia.

Dapat disimpulkan dengan mempertimbangkan keluarnya sektor basic metal sebagai salah satu sektor utama penyumbang nilai ekspor terbesar baik itu pada struktur ekspor Indonesia ke Kanada atau sebaliknya. Kajian yang lebih mendalam tentu sangat diperlukan untuk menjawab hal tersebut. Terlepas dari keutamaan keempat sektor di atas, Indonesia juga bukan merupakan pasar utama bagi Kanada. Hal ini terlihat pada persentase market share dari keempat sektor utama penyumbang nilai ekspor Kanada ke Indonesia terbesar, yakni sebesar kurang dari 2\% untuk keempat sektor tersebut.

\section{Tabel 8. Sepuluh Sektor Utama Untuk Ekspor Kanada ke Indonesia}

\begin{tabular}{llrr}
\hline No. & \multicolumn{1}{c}{ Sectors } & $\begin{array}{c}\text { total export } \\
\text { (million USD) }\end{array}$ & \%total \\
\hline 1 & Wholesale trade, except of motor vehicles and motorcycles & 6008.08 & $14.6 \%$ \\
2 & Land transport and transport via pipelines & 5086.78 & $12.3 \%$ \\
3 & Computer programming, consultancy and related activities; & 3581.62 & $8.7 \%$ \\
& information service activities & & \\
4 & Manufacture of other transport equipment & 2766.40 & $6.7 \%$ \\
5 & Accommodation and food service activities & 2330.55 & $5.6 \%$ \\
6 & Financial service activities, except insurance and pension & 1826.33 & $4.4 \%$ \\
7 & funding & & \\
8 & Manufacture of computer, electronic and optical products & 1456.70 & $3.5 \%$ \\
& Manufacture of food products, beverages and tobacco & 1402.64 & $3.4 \%$ \\
9 & products & & \\
10 & Mining and quarrying & 1330.83 & $3.2 \%$ \\
\hline Sumber: WIOD (2019) & 1301.26 & $3.2 \%$ \\
\hline
\end{tabular}

Mengacu kembali ke pernyataan awal, ekspor kedua negara didominasi oleh produk intermediate. Oleh karena itu, penting untuk dilihat struktur ekspor dengan mempertimbangkan jenis dari barang yang diekspor. Tabel 9 menyajikan sepuluh sektor utama dengan nilai ekspor terbesar untuk intermediate input pada ekspor Indonesia ke Kanada. Secara umum 
dapat ditunjukkan bahwa kontribusi lima sektor sudah mencapai $61 \%$ dari total ekspor produk intermediate Indonesia ke Kanada. Kelima sektor tersebut adalah sektor basic metal, sektor karet dan produk plastik, sektor kimia, sektor tekstil, pakaian jadi dan produk kulit, dan sektor fabricated metal products. Kondisi ini mencerminkan bahwa kelima sektor tersebut cukup penting bagi industri Kanada.

\section{Tabel 9. Sepuluh Sektor Dengan Nilai Ekspor Terbesar Untuk Intermediet Input Dalam Struktur Ekspor Indonesia ke Kanada}

\begin{tabular}{clrr}
\hline No & \multicolumn{1}{c}{ Sectors } & $\begin{array}{c}\text { Export } \\
\text { (million USD) }\end{array}$ & \%total \\
\hline 1 & & 311.62 & $40 \%$ \\
2 & Manufacture of rubber and plastic products & 86.21 & $11 \%$ \\
3 & Manufacture of furniture; other manufacturing & 82.46 & $11 \%$ \\
4 & Manufacture of computer, electronic and optical products & 44.44 & $6 \%$ \\
& Manufacture of food products, beverages and tobacco & & \\
5 & products & 39.09 & $5 \%$ \\
6 & Manufacture of textiles, wearing apparel and leather products & 31.28 & $4 \%$ \\
7 & Crop and animal production, hunting and related service & & \\
8 & Manufacture of basic metals & 30.24 & $4 \%$ \\
9 & Manufacture of paper and paper products & 28.22 & $4 \%$ \\
& Manufacture of wood and of products of wood and cork, except & 28.14 & $4 \%$ \\
10 & furniture; manufacture of articles of straw and plaiting materials & & \\
\hline
\end{tabular}

Sumber: WIOD (2019)

Sektor manufacture of rubber and plastic products terlihat cukup dominan dengan persentasenya mencapai 40\%, jauh di atas sektor manufacture of furniture; other manufacturing. Hal ini mengindikasikan pernyataan sebelumnya bahwa sektor manufacture of rubber and plastic product merupakan sector tertinggi dalam ekspor Indonesia ke Kanada.

Jika mempertimbangkan aliran perdagangan sebaliknya, yakni ekspor
Kanada ke Indonesia, maka untuk produk intermediate, ekspor Kanada didominasi oleh hanya dua sektor utama, yakni sektor Crop and animal production, hunting and related service activities. Secara bersama-sama kedua sektor tersebut menyumbang sebesar $38 \%$ dari nilai total ekspor Kanada ke Indonesia untuk kategori barang input intermediate. Tabel 10 juga menunjukkan bahwa ekspor sektor manufaktur Kanada ke Indonesia juga 
cukup besar, namun jauh lebih kecil sebesar 14\%, jauh lebih kecil dibandingkan sektor yang telah dibandingkan sektor Crop and animal dipaparkan sebelumnya. Persentase ekspor sektor manufaktur hanya production, hunting and related service activities.

Tabel 10. Sepuluh Sektor Dengan Nilai Ekspor Terbesar Untuk Intermediet Input Dalam Struktur Ekspor Kanada ke Indonesia

\begin{tabular}{llrr}
\hline No & \multicolumn{1}{c}{ Sectors } & $\begin{array}{c}\text { Export } \\
\text { (million USD) }\end{array}$ & $\begin{array}{c}\text { \% } \\
\text { total }\end{array}$ \\
\hline 1 & Crop and animal production, hunting and related service & 374.29 & $38 \%$ \\
& activities & 137.67 & $14 \%$ \\
2 & Manufacture of chemicals and chemical products & 134.13 & $14 \%$ \\
3 & Manufacture of paper and paper products & 43.10 & $4 \%$ \\
4 & Mining and quarrying & 37.88 & $4 \%$ \\
5 & Manufacture of other transport equipment & 36.39 & $4 \%$ \\
6 & Manufacture of machinery and equipment n.e.c. & 36.23 & $4 \%$ \\
7 & Manufacture of food products, beverages and tobacco & 16.34 & $2 \%$ \\
& products & 15.95 & $2 \%$ \\
9 & Manufacture of computer, electronic and optical products & 14.70 & $2 \%$ \\
\hline
\end{tabular}

Sumber: WIOD (2019)

Sejalan dengan kategori produk input intermediate, ekspor Indonesia ke Kanada yang selanjutnya digunakan sebagai final product juga didominasi oleh hanya dua sektor, yakni sektor tekstil, pakaian jadi dan produk kulit, dan sektor makanan jadi dan minuman. Sektor tekstil, pakaian jadi dan produk kulit memang merupakan salah satu sektor ekspor unggulan Indonesia ke dunia, bukan hanya Kanada. Namun jika dilihat dari besaran persentase kedua sektor di atas yang mencapai 75\%, maka menunjukkan adanya peluang untuk meningkatkan ekspor Indonesia ke Kanada khususnya pada sektor selain sektor tekstil, pakaian jadi dan produk kulit, dan sektor makanan jadi dan minuman. 


\begin{tabular}{|c|c|c|c|}
\hline \multicolumn{4}{|c|}{ Produk Akhir Dalam Struktur Ekspor Indonesia ke Kanada } \\
\hline No & Sectors & $\begin{array}{c}\text { Export } \\
\text { (million } \\
\text { USD) }\end{array}$ & $\begin{array}{l}\% \\
\text { total }\end{array}$ \\
\hline 1 & Manufacture of textiles, wearing apparel and leather products & 649.74 & $55 \%$ \\
\hline 2 & Manufacture of food products, beverages and tobacco products & 234.37 & $20 \%$ \\
\hline 3 & Manufacture of furniture; other manufacturing & 57.61 & $5 \%$ \\
\hline 4 & Manufacture of rubber and plastic products & 35.31 & $3 \%$ \\
\hline 5 & Other service activities & 30.56 & $3 \%$ \\
\hline 6 & Manufacture of machinery and equipment n.e.c. & 29.97 & $3 \%$ \\
\hline 7 & $\begin{array}{l}\text { Crop and animal production, hunting and related service } \\
\text { activities }\end{array}$ & 26.16 & $2 \%$ \\
\hline 8 & Manufacture of chemicals and chemical products & 22.38 & $2 \%$ \\
\hline 9 & $\begin{array}{l}\text { Manufacture of basic pharmaceutical products and } \\
\text { pharmaceutical preparations }\end{array}$ & 22.26 & $2 \%$ \\
\hline 10 & $\begin{array}{l}\text { Manufacture of fabricated metal products, except machinery and } \\
\text { equipment }\end{array}$ & 14.46 & $1 \%$ \\
\hline
\end{tabular}

Sumber: WIOD (2019)

Struktur ekspor Kanada ke Indonesia untuk kategori produk final Indonesia untuk produk yang dijadikan dikontribusikan oleh sektor wholesale final product, juga tidak jauh berbeda. trade, except of motor vehicles and $68 \%$ dari total nilai ekspor Kanada ke motorcycles yaitu sebanyak $15 \%$.

Tabel 12. Sepuluh Sektor Dengan Nilai Ekspor Terbesar Untuk Kategori Produk Akhir Dalam Struktur Ekspor Kanada ke Indonesia

\begin{tabular}{clrr}
\hline No & \multicolumn{1}{c}{ Sectors } & $\begin{array}{c}\text { Export } \\
\text { (million USD) }\end{array}$ & \%total \\
\hline 1 & Wholesale trade, except of motor vehicles and motorcycles & 6006.47 & $15 \%$ \\
2 & Land transport and transport via pipelines & 5085.92 & $13 \%$ \\
3 & Computer programming, consultancy and related activities; & 3580.76 & $9 \%$ \\
& information service activities & & \\
4 & Manufacture of other transport equipment & 2728.52 & $7 \%$ \\
5 & Accommodation and food service activities & 2317.47 & $6 \%$ \\
6 & Financial service activities, except insurance and pension & 1825.39 & $5 \%$ \\
& funding & & \\
7 & Manufacture of computer, electronic and optical products & 1440.35 & $4 \%$ \\
8 & Manufacture of food products, beverages and tobacco products & 1366.42 & $3 \%$ \\
9 & Mining and quarrying & 1287.73 & $3 \%$ \\
10 & Manufacture of machinery and equipment n.e.c. & 1264.88 & $3 \%$ \\
\hline
\end{tabular}

Sumber: WIOD (2019) 
Oleh karena itu, Indonesia perlu meningkatkan keterkaitan dalam rantai nilai global. Strategi GVC, menawarkan peluang ekonomi baru bagi offshoring bagian dari proses produksi mereka, dan karena itu "upgrade" dalam rantai nilai. Indonesia perlu lebih fokus pada industri yang maju dan backward linkage yang telah diatur sedemikian rupa sehingga sumber daya tidak terbuang untuk membuat hubungan baru. Indonesia memiliki peluang besar di bidang peralatan elektronik, manufaktur kendaraan, dan pertanian. Guna meningkatkan partisipasi Indonesia dalam GVC, maka strategi yang dapat dilakukan:

1. Meningkatkan daya saing dalam negeri di kedua saing biaya dan kapasitas daya saing, khususnya: akses murah untuk pembiayaan

2. Memperbaiki iklim investasi untuk menarik FDI ke Indonesia

3. Meningkatkan Inovasi dan Kualitas SDM Domestik

4. Peningkatan Standar Mutu Produksi begitu bertemu dengan Standar Internasional

5. Meningkatkan Hubungan Antara Lokal dan Internasional Perusahaan
KESIMPULAN DAN REKOMENDASI KEBIJAKAN

Kontribusi Indonesia dalam GVC masih rendah, hal ini dapat dilihat dari nilai intermediate input yang lebih rendah dibandingkan dengan nilai final input. Bila dibandingkan dengan negara-negara lain ASEAN (yang memiliki ekspor terbesar ke Kanada), yaitu Vietnam, Thailand, dan Malaysia, persentase ekspor intermediate input Indonesia hanya sebesar 48,3\% dimana jumlah tersebut lebih rendah dibandingkan dengan Negara-negara tersebut. Jika nilai intermediate inputnya tinggi maka Negara tersebut memiliki keterkaitan rantai nilai global yang lebih bagus.

Oleh karena itu, Indonesia perlu memanfaatkan peluang yang ada sehingga sektor-sektor di Indonesia dapat berpartisipasi dalam rantai nilai global, terutama pada sektor-sektor yang memiliki nilai tambah tinggi.

\section{UCAPAN TERIMA KASIH}

Penulis mengucapkan terima kasih kepada seluruh redaksi Buletin IImiah Litbang Perdagangan, Mitra Bestari, dan seluruh pihak terkait atas kesempatan, kontribusi, dan bantuan yang telah diberikan dalam penulisan karya tulis ini. 


\section{DAFTAR PUSTAKA}

Ahmad, Tauhid, dkk. (2018). Global Value Chain Of Indonesian Pulp And Paper Industry. Jurnal Manajemen \& Agribisnis, Vol. 15 No. 2.

Badan Pusat Statistik (BPS). (2020). Sistem Informasi Statistik Ekspor Impor. Diakses dari http://sister.kemendag.go.id/?token= 548YOa3CNxnP\&sess id=ilmgdauk m2s5fdaiq2tond7ol9jhkf42

Banga, Karishma. (2016). Impact of Global Value Chains on Employment in India. Journal of Economic Integration. Vol.31 No.3, September 2016, 631673.

Chen, et al. (2019). Global overview for energy use of the world economy: Householdconsumption-based accounting based on the world inputoutput database (WIOD). Elsevier Journal, Energy Economics Volume 81, June 2019, Pages 835-847

Dedrick J, Kraemer KL, Linden G. (2010). Who Profits From Innovation in Global Value Chains?: A Study of The Ipod and Notebook PCs. Industrial and Corporate Change 19(1):81-116. https://doi.org/10.1093/icc/dtp032

EU-Indonesia Trade Cooperation Facility. (2015). Diakses dari https://ec.europa.eu/europeaid/projec ts/eu-indonesia-trade-cooperationfacility-tcf en

Gereffi, G; Stark, KF. (2011). Global Value Chain Analysis: A Primer.

Gereffi, G. (2014). A Global Value Chain Perspective on Industrial Policy And Development In Emerging Markest. Duke Journal of Comparative \& International Law 24: 433.

Hummels, et al. (2001). The Nature and Growth of Vertical Specialization in Worls Trade. Journal of International Economics, Elsevier Volume 54, Issue 1, June 2001, Pages 75-96.
Ingot, Steven Raja., \& Laksani, Dian Dwi. (2019). Indonesia Global Value Chain Participation in Regional Comprehensive Economic Partnership (RCEP). Advances in Economics, Business and Management Research.

Johnson, R; Noguera, G. (2012). Accounting for Intermediates: Production Sharing And Trade in Value-Added. Journal of International Economics $\quad 86(2):$ 224-236. https://doi.org/10.1016/j.jinteco.2011. 10.003

Koopman, R; Powers, W; Wang, Z; Wei SJ. (2010). Give Credit to Where Credit is Due: Tracing Value Added In Global Production Chains. NBER Working Paper 16426.

Kuboniwa, Masaaki. (2014). Russia's Global Value Chain using a Modified World Input-Output Data, Japan: Institute of Economic Research Hitotsubashi University.

Lu, Yingying. (2017). China's electrical equipment manufacturing in the global value chain: A GVC income analysis based on World Input-Output Database (WIOD). Elsevier Journal, International Review of Economics and Finance No 52 (2017) 289-301.

Meng, B. (2011). Trade Pattern and Global Value Chain in East Asia: From Trade in Goods to Trade in Tasks. World Trade Organizations IDE JETRO. Diakses dari https://www.wto.org/english/res e/bo oksp e/stat tradepat globvalchains e.pdf

OECD. (2019). Guide to OECD's Trade in Value Added (TiVA) Indicators. OECD, Directorate for Science, Technology and Innovation.

Rubinova, Stela. (2017). The Impact of New Regionalism on Global Value Chains Participation. Geneva: CTEI Working Papers. 
Skabic, Ines Kersan. (2019). The drivers of global value chain (GVC) participation in EU member states. Diakses dari: https://www.tandfonline.com/doi/full/1 0.1080/1331677X.2019.1629978

Sudhana, Pranakusuma. (2017). Tinjauan Posisi Industri Tekstil dan Produk Tekstil Indonesia dalam Global Value Chain. Seminar Nasional Sains dan Teknologi Terapan V 2017. Diakses dari:

https://core.ac.uk/download/pdf/2897 05284.pdf

The Economist Intelligence Unit. (2020). Diakses dari https://data.eiu.com/Default.aspx?pu btype id=913181276.

The Global Value Chains Initiative. (2019). Concepts \& Tools. Diakses dari http://www.globalvaluechains.org/

Timmer, MP; Erumban, AA; Los, B; Stehrer, R; Gaaitzen, J; De Vries. (2014). Sciling up Global Value Chains. Journal of Economics Perspectives 28(2): $\quad$ 99- 118. https://doi.org/10.1257/jep.28.2.99
Timmer, M. P., Los, B., Stehrer, R. \& de Vries, G. J. (2016). An Anatomy of the Global Trade Slowdown based on the WIOD 2016 Release. GGDC research memorandum number 162, University of Groningen.

Trademap. (2020). Diakses dari https://www.trademap.org/Index.aspx

WIOD. (2019). Diakses dari http://www.wiod.org/database/wiots1 $\underline{6}$

Xing, L. (2017). Analysis of Inter-country Input-Output Table Based on Citation Network: How to Measure the Competition and Collaboration between Industrial Sectors on the Global Value Chain, PLos ONE 12 (9): e0184055

Zhou, et al. (2019). Global value chain, regional trade networks and Sino-EU FTA. Elsevier Journal, Structural Change and Economic Dynamics Volume 50, September 2019, Pages 26-38. 